\title{
Evaluation of Machine
} Guarding Pilot Course Taught in Idaho Falls, Idaho June 23, 1992 - June 25, 1992

\section{T. S. Wright}

October 1992

Prepared for the U.S. Department of Energy under Contract DE-AC06-76RLO 1830

Pacific Northwest Laboratory Operated for the U.S. Department of Energy by Battelle Memorial Institute 


\title{
DISCLAIMER
}

This report was prepared as an account of work sponsored by an agency of the United States Government. Neither the United States Government nor any agency thereof, nor Battelle Memorial Institute, nor any of their employees, makes any warranty, expressed or implied, or assumes any legal liability or responsibility for the accuracy, completeness, or usefulness of any information, apparatus, product, or process disclosed, or represents that its use would not infringe privately owned rights. Reference herein to any specific commercial product, process, or service by trade name, trademark, manufacturer, or otherwise does not necessarily constitute or imply its endorsement, recommendation, or favoring by the United States Government or any agency thereof, or Battelle Memorial institute. The views and opinions of authors expressed herein do not necessarily state or reflect those of the United States Government or any agency thereof.

\author{
PACIFIC NORTHWEST LABORATORY \\ operated by \\ BATTELLE MEMORIAL INSTITUTE \\ for the \\ UNITED STATES DEPARTMENT OF ENERGY \\ under Contract DE-ACO6-76RLO 1830
}

Printed in the Uniled States of America

Available to DOE and DOE contractors from the

Office of Scientific and Technical Information, P.O. Box 62, Oak Ridge, IN 37831 . prices available from (615) 576-8401. FTS 626-8401.

Available to the public from the National Technical Information Service, U.S. Department of Commerce, 5285 Port Royal Rd., Springfield, VA 22161. 
EVALUATION OF MACHINE GUARDING PILOT COURSE TAUGHT IN IDAHO FALLS, IDAHO JUNE 23, 1992 - JUNE 25, 1992

T.S. Wright

October 1992

Prepared for the U.S. Department of Energy under Contract DE-ACO6-76RLO 1830

Pacific Northwest Laboratory Richland, Washington 99352 


\subsection{SUMMARY}

This section summarizes trainee evaluations for the Safety Training Section course, Machine Guarding which was conducted June 23-25 at the Westinghouse Idaho Nuclear Company, in Idaho Falls, Idaho. This class was the fourth pilot course taught.

Sections 1.1 and 1.2 of this report summarize the quantitative course evaluations that trainees provided upon completion of the course. Appendix $A$ provides a transcript of the trainees' written comments.

This class was conducted concurrently with a "Supervisors Orientation to Occupational Safety in DOE" class. This allowed the lead instructor to use two experts in the classes without additional cost. The experiment was successful, both from a standpoint of cost and quality. The same format (concurrent classes) will be used at the Nevada test site in October. 


\section{CONTENTS}

1.0 SUMMARY--WESTINGHOUSE IDAHO NUCLEAR COMPANY JUNE 23 TO 25, 1992) . . ii 1.1 SUMMARY OF TRAINEE COURSE EVALUATIONS AT INEL . . . . . . . . . . 1.1 1.2 NUMERIC RATINGS . . . . . . . . . . . . . . . . 1.1 1.3 WRITTEN COMMENTS . . . . . . . . . . . . . . . . 1.3

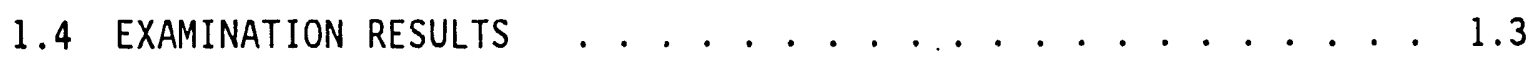

1.4 SUGGESTIONS FOR IMPROVEMENT . . . . . . . . . . . . . . 1.5 APPENDIX A - EVALUATION COMMENTS . . . . . . . . . . . . . . . . . A.1 APPENDIX B - TRAINEE EVALUATION FORM . . . . . . . . . . . . . . . B. 1 


\subsection{SUMMARY OF TRAINEE COURSE EVALUATION AT IDAHO FALLS}

This course was conducted at INEL for DOE, in Idaho Falls, Idaho, June 23-25, 1992. Tommye Wright, Carl Heise and Troy Corbin presented the course to forty-one persons.

\subsection{NUMERIC RATINGS}

Forty-one trainees completed a course evaluation form upon finishing the course. The first rating area of the form covered six items dealing with course content; the second rating area covered one item dealing with testing materials; and the third rating area covered ten items specifically associated with course topic areas.

For the first and second rating areas, respondents were instructed to rate the degree to which they agreed or disagreed with each statement using a five-point scale with 1 (low) anchored to "strongly disagree" and 5 (high) anchored to "strongly agree". The ratings are as follows:

\section{COURSE CONTENT AND TESTING MATERIALS RATINGS}

1. Developed specific skills and competencies in machine safeguarding that I can use on the job.

Average Class Rating - $\underline{4.18}$

2. Gained factual knowledge about machine safeguarding (terminology, classifications, regulations).

Average Class Rating - $\underline{4.25}$

3. Learned fundamental principles, generalizations, and theories. Average Class Rating - $\underline{4.15}$

4. Can use the course materials to improve thinking, problem-solving, and decision-making in my work.

Average Class Rating - $\underline{4.23}$

5. Would recommend this course to others.

Average $\mathrm{Cl}$ ass Rating - $\underline{4.28}$ 
6. This course will help others to make their work environments safer. Average Class Rating - $\underline{4.25}$

7. The final test was a good measure of the knowledge gained in the course. Average Class Rating - $\underline{3.80}$

The average class rating for the course content area and testing materials area was 4.16 .

The third rating area asked the respondents to rate the value of each of the fifteen topic areas using a five-point scale with 1 (Unsatisfactory), 2 (Satisfactory), 3 (Good), 4 (Very Good), or 5 (Excellent). The following are the average class ratings that dealt with topic content as well as with the value of the instructor:

\begin{tabular}{|c|c|c|c|}
\hline INSTRUCTOR & TOPICAL AREAS PRESENTED & CONTENT & INSTRUCT \\
\hline Tommye Wright & $\begin{array}{l}\text { Foundation (The Act, } 1960, \\
\text { Executive Order) }\end{array}$ & 3.25 & 3.65 \\
\hline Carl Heise & ANSI Standards & 3.78 & 4.00 \\
\hline Carl Heise & Subparts D \& I & 3.15 & 3.63 \\
\hline Troy Corbin & Lockout/Tagout & 4.13 & 4.33 \\
\hline Tommye Wright & Accident Reports & 4.13 & 4.40 \\
\hline Carl Heise & $\begin{array}{l}\text { Concepts \& Techniques of Machine } \\
\text { Guarding }\end{array}$ & 4.10 & 4.23 \\
\hline Carl Heise & Subpart 0 & 3.53 & 3.95 \\
\hline $\begin{array}{l}\text { Carl Heise and } \\
\text { Tommye Wright }\end{array}$ & Shop Inspection & 4.10 & 4.25 \\
\hline Carl Heise & Subparts $P \& S$ & 3.53 & 3.95 \\
\hline Carl Heise & Machine Safeguarding Workshops & 3.93 & 4.25 \\
\hline
\end{tabular}

The overall average class rating for specific topic content was 3.76 . The overall average class ratings for the instructors were: Tommye Wright 4.06, Carl Heise 4.04 and Troy Corbin 4.33. 


\subsection{WRITTEN COMMENTS}

After providing numeric course evaluations, participants provided written comments about the course. Written comments were transcribed and are presented verbatim in Appendix A.

\subsection{EXAMINATION RESULTS.}

On the last day of the course, a final examination was administered to forty-one attendees. There were 25 questions, all multiple choice. The scores ranged from $70 \%$ to $100 \%$ with the average score being $89 \%$. Forty persons successfully completed the course.

\subsection{SUGGESTIONS FOR IMPROVEMENT}

From the comments, it was apparent that two sections are in need of revision, "Foundation and DOE Orders" and "ANSI Standards". Revision is in progress for both sections.

More visuals are being prepared for this class. A photography session has been set up for September 4, 1992 to acquire better quality visuals. In addition, future classes will focus primarily on Subpart 0 . In this and other classes, Subparts I and D were not considered helpful and will be deleted. These changes should help focus the class on the needs of the DOE sites. 
APPENDIX A

\section{EVALUATION COMMENTS}

MACHINE GUARDING

JUNE 23, 1992 - JUNE 25, 1992

IDAHO FALLS, ID (WESTINGHOUSE IDAHO NUCLEAR COMPANY) 
APPENDIX A

\section{TRAINEE EVALUATION RESPONSES}

MACHINE GUARDING

JUNE 23-25, 1992--IDAHO FALLS, ID

WESTINGHOUSE IDAHO NUCLEAR COMPANY

Please briefly describe how your expectations of this course were or were not met.

We need a definite set of workable rules for the use of interpretation of 1910 .

Goi definitive answers to machine guarding standard.

I gained a foundation in code books and factual knowledge.

A11 were exceeded.

Expectations definitely exceeded.

No real definitive answers.

General idea of how inspectors used 1910.

Good class. Gave me insight of what OSHA wants.

Provided a good review of machine guarding requirements. Will use the material in a machine guarding task force.

Good review of standards.

They were met.

I really wanted more specifics to help us fix it right the first time but I learned they were judgement calls.

I had no idea what the objective of the course was going to be. I now have a good understanding of the machine guarding standard.

My intent was to gain a better understanding of the OSHA requirements. I feel that was accomplished. 
All expectations were more than met.

I wanted to see some before/after engineering controls that I could use in my work place.

Most part were review to me. Thought it was good insight for management people and auditors.

Yes, gained an awareness of "the rule".

Exceeded expectations.

The most helpful topics covered or activities presented in this course were: A11.

Identifying potential hazards.

Machine guarding.

Using 29 CFR.

Subpart 0 .

I thought the lab session was very helpful.

Guarding.

Walk around.

The common sense approach to assessments.

Machine guarding.

Interpretations of standards.

Learning the code book.

Familiarization with and use of the code of federal regulations book.

Workshop \#2. Discussion of subpart 0 .

Electrical requirements.

That the OSHA standards can be used for your intended purposes.

Intent of standards and regulations verse compliance.

How to work the CFR book. 
The least helpful things disiussed or done were:

Electrical.

Lock out and tag out.

Introduction to OSHA.

None.

I don't believe there were any, they were all most helpful.

Abrasive wheel guarding.

A11 were most helpful.

Several machines were not applicable to our work force.

Electrical.

More emphasis should be given to:

Machines and proper shielding.

Walk around pictures.

Personnel concerns for safety problems.

PPE.

Codes and requirements.

ANSI, since they interacted.

The transition point between using or not using PPE.

Software controls for automated equipment.

Lockout/Tagout and electrical.

Good as it.

\section{Less emphasis should be given to:}

Tests.

Good as is.

War stories.

None as notes 
Types of machinery I don't have.

What specific suggestions do you have for improving future sessions? No specific ideas!

Better classroom facilities.

Better video presentation equipment, ton small picture for large room. Smaller groups.

Smaller groups for more group interaction.

More specific audience to my background and needs.

Longer class (5) day.

Other materials to supplement or substitute for the provided handouts?

Concepts and techniques of machine guarding.

More information on industrial hygiene.

ANSI standards to cover some parts of subpart 0 .

Daily schedule/timing of activities, worktime?

Very good.

Okay.

Good.

Good schedule.

Great.

Well laid out.

Everything went in a timely manner.

Facilities/training room arrangements?

Good.

Okay.

Good air conditioning. 
The facilities were poor. Poor lighting for slides, poor refreshments, generally cramped quarters.

Facility was poor. Projection equipment did not work windows could not be properly darkened for projection use.

Adequate.

Room could have been better.

Not bad.

Satisfactory.

No soft drinks.

Could have been elsewhere (Shilo Inn).

What other types of safety training courses would you like to see available? Course on electrical safety (NEC) (NESC).

Chemical laboratory safety related courses.

HAZCOM.

Other areas of OSHA regulations. Material handling, subpart $F$.

Electrical based courses.

Power tools.

Any further comments?

Best OSHA class I have yet to attend.

An informative, practical and useful course.

Very good course. Carl was very impressive.

Basic course was very well presented.

Good hands-on by conducting the inspection the reviewing first in small groups than with all.

The staff. Carl, Tommye and Troy are true professionals and this course is needed through out our entire organization. 


\section{APPENDIX B}

IRAINEE EVALUATION FORM 
EVALUATIONFORM

Machine Guarding
Date

Name (optional)

Titie

Location

Please evaluate various features of the course you have just completed. The information you provide here will be combined with that from other trainees and summarized for the sponsor, the U.S. Department of Energy. Results from this evaluation will be used to improve this course.

\section{Course Content}

Overall, as a result of this course I believe that I:

developed speciflc skills and competencies in machine

safeguarding that I can use on the job

gained factual knowledge about machine safeguarding

(terminology, classifications, regulations).

leamed fundamental principles, generalizations,

and theories.

can use the course materials to improve thinking,

problem-solving, and decision-making in my work.

would recommend this course to others.

Strongly

Agres

Agree

Noither Agree

nor Disagres Disagree

Strongly

Disagree

this course will help others to make their work

environments safer.

.......................................................................

Strongly

Testing Materials

The find test was a good measure of the

knowledge gained in the course.

Agree Agree
.5

.5

$$
4
$$

4

4

4

4

4

4
3

3

3

3

3

3

Noithir Agree

nor Disagres Disagres

3

2
2

2

2

2

2

2

Strongly

Disagree

\section{Topic Areas}

Please evaluate each topic area using the 5-point scale below.
5 Excellent
4 Very Good 3 Good
1 Unsatisfactory

1. Foundation (The Act, Executive Order)

Contant

2. ANSI Standards ...............................................................5 $4 \begin{array}{lllll} & 3 & 2 & 1\end{array}$

$\begin{array}{lllll}5 & 4 & 3 & 2 & 1\end{array}$

3. Concepts and Techniques of Machine Safeguarding ................5 $54 \begin{array}{llll}4 & 4 & 2 & 1\end{array}$

4. Subpart O

$\begin{array}{lllll}5 & 4 & 3 & 2 & 1\end{array}$

5. Accident Reports

$\begin{array}{llll}4 & 3 & 2 & 1\end{array}$

6. LockoutTagout

7. Subparts D and I

$\begin{array}{llll}4 & 3 & 2 & 1\end{array}$

8. Subparts $P$ and $S$

9. Shop Inspection

10. Machine Safeguarding Workshops

.5

Instructor

$\begin{array}{lllll}\mathbf{5} & \mathbf{4} & \mathbf{3} & \mathbf{2} & \mathbf{1} \\ \mathbf{5} & \mathbf{4} & \mathbf{3} & \mathbf{2} & 1 \\ \mathbf{5} & \mathbf{4} & \mathbf{3} & 2 & 1 \\ \mathbf{5} & \mathbf{4} & \mathbf{3} & 2 & 1 \\ \mathbf{5} & \mathbf{4} & \mathbf{3} & 2 & 1 \\ \mathbf{5} & \mathbf{4} & \mathbf{3} & 2 & 1 \\ \mathbf{5} & \mathbf{4} & \mathbf{3} & 2 & 1 \\ \mathbf{5} & \mathbf{4} & \mathbf{3} & \mathbf{2} & 1 \\ \mathbf{5} & \mathbf{4} & \mathbf{3} & \mathbf{2} & 1 \\ \mathbf{5} & \mathbf{4} & \mathbf{3} & \mathbf{2} & 1\end{array}$




\section{Comments}

1. Please briefly describe how your expectations of this course were or were not met.

2. The most helpful topics covered or activities presented in this course were:

3. The least helpful topics or activities in this course were:

4. More emphasis should be given to:

5. Less emphasis should be given to:

6. What specific suggestions do you have for improving future sessions?

7. Other materials to supplement or substitute for the provided handouts?

8. Daily schedule/timing of activities, worktime?

9. Facilities/training room arrangements?

10. What other types of safety training courses would you like to see available?

11. Any further comments?

12. Overall rating: Based on your comments above, please rate the course on a 5-point scale by circling the number of your choice.
5 Excellent
4 Very Good 3 Good
2 Satistactory
1 Unsatisfactory 
No. of

Copies

\section{OFFSITE}

12 DOE/Office of Scientific and Technical Information

R. E. Gibbs

Office of Safety and Quality Programs

U.S. Department of Energy 19901 Germantown Rd. Germantown, MD 20874

G. R. Florczak

U.S. Department of Energy

EH 31.2

19901 Germantown Rd.

Germantown, MD 20874

C. H. Heise

1145 Saddle Ridge

Portage, WI 53901

Troy Corbin

Marine and Environmental

Testing

P.0. Box 5693

Portland, OR 97228-5693

Wayne Buisman

DOE Idaho Falls

785 DOE Place

Idaho Falls, ID 83402
No. of

Copies

ONSITE

DOE Richland Field Office

P. W. Kruger

13 Pacific Northwest Laboratory

H. N. Bowers

T. S. Wright

M. A. Leckband (5)

Publishing Coordination

Technical Report Files (5) 

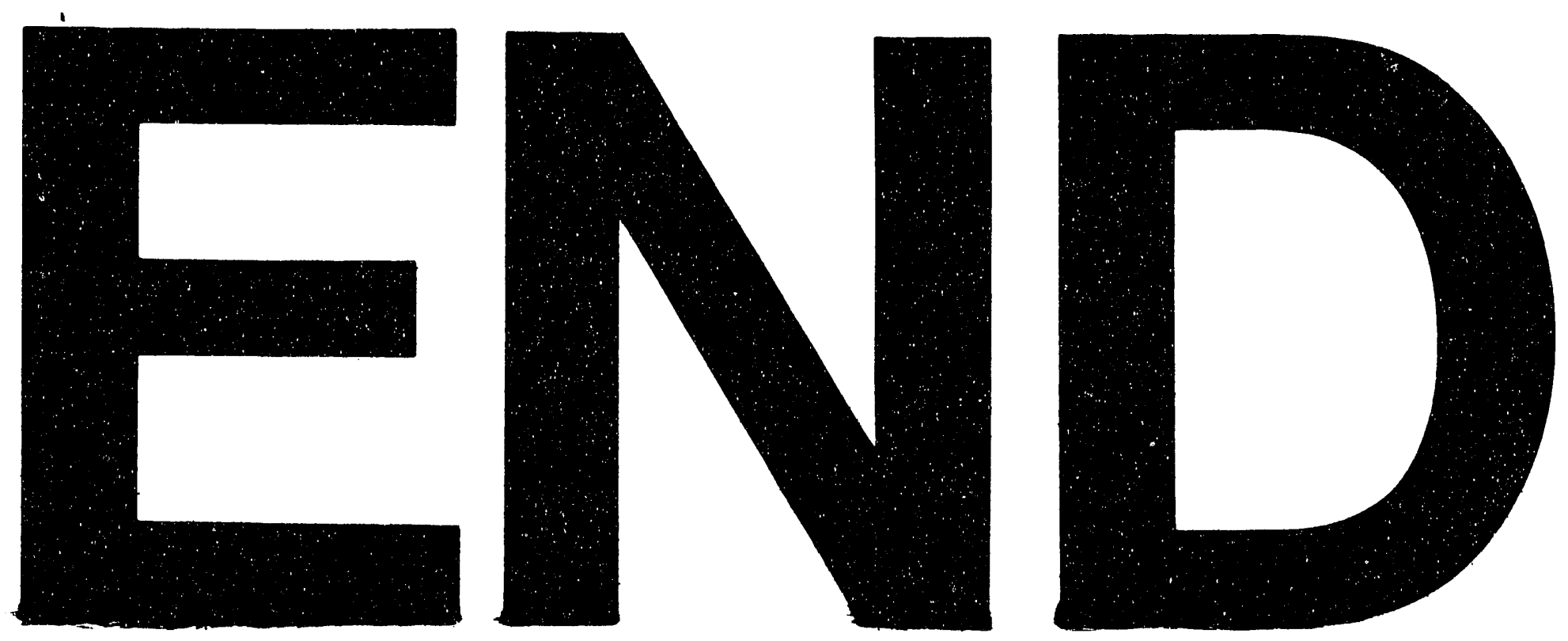

$\longrightarrow$

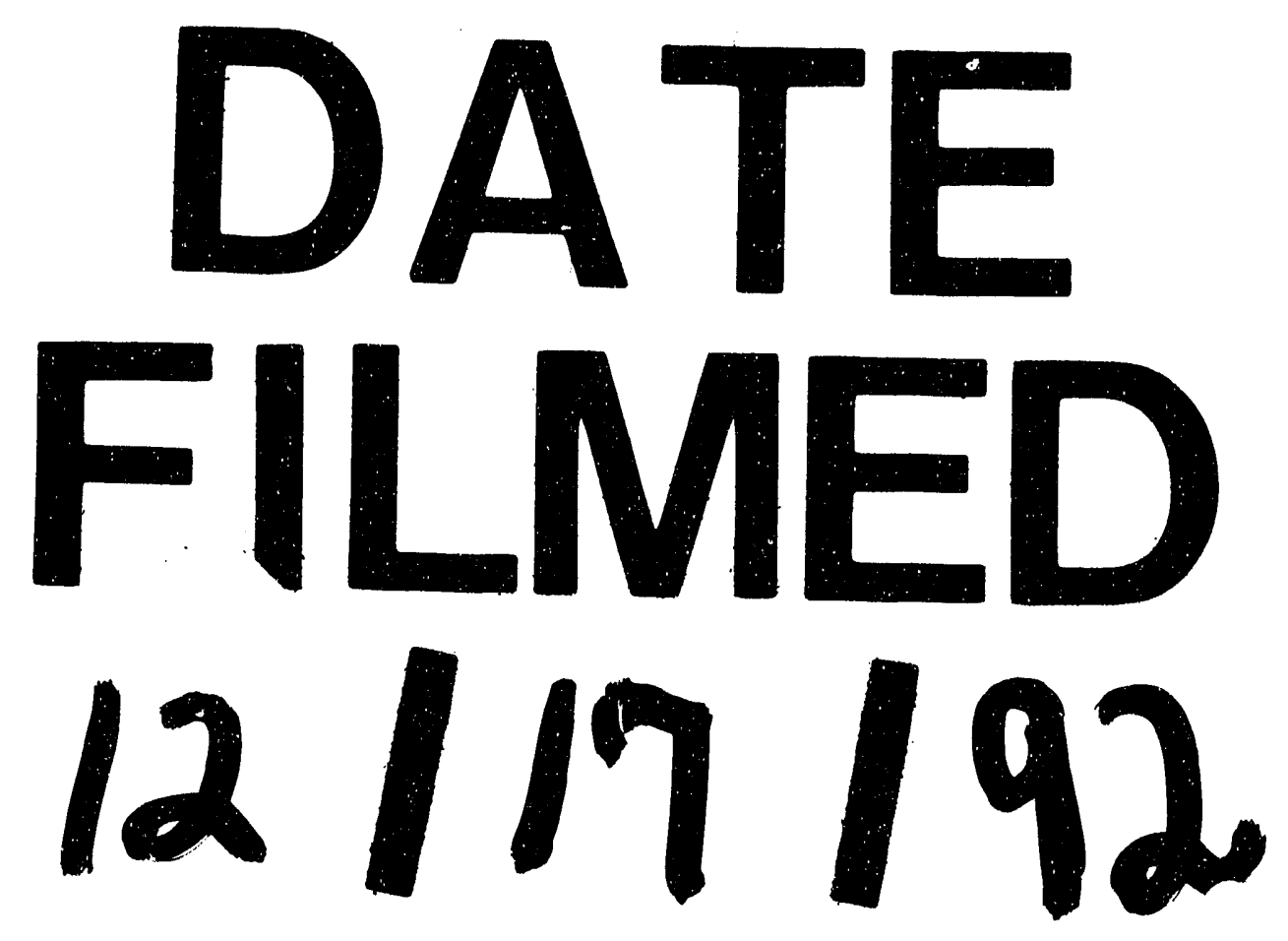


